\title{
Re: Insight into ECMO, mortality and ARDS: a nationwide analysis of 45,647 ECMO runs (Friedrichson et al., Critical Care, January 2021)
}

\author{
Alex Warren ${ }^{1}$, Luigi Camporota ${ }^{2,3},{\text { Stephane } \text { Ledot }^{4}, \text { Ian Scott }^{5} \text { and Alain Vuylsteke }}^{6^{*}}$ (i)
}

\section{To the editor}

We read with interest the well-conducted analysis presented by Friedrichson et al. on the provision of ECMO in Germany from 2007 to 2018 [1].

The authors note that by 2018 , there were 231 centres in Germany providing veno-venous ECMO support (VVECMO), with a median case volume of 4 patients per year; $70 \%$ of centres reported 10 or fewer cases annually. In the United Kingdom, since 2011, ECMO for respiratory failure has been provided by six centres in a hub-and-spoke network [2], similar to that the authors propose. We estimate from the data provided that in 2018, Germany had one VV-ECMO centre per 358,000 head of population; in the UK this figure was one per 11 million [3]. Our recent analysis of the first six years of this service demonstrated a median annual case volume of 37.5 patients per centre and overall ICU mortality of $26 \%$ [2].

There are likely multiple factors explaining the discrepancy between the UK data and the hospital mortality of $54 \%$ reported by Friedrichson et al. [1]. Firstly, even including neonatal and paediatric patients, $70 \%$ of patients receiving VV-ECMO in the German study were aged above 50; for the UK dataset, the corresponding figure was $33 \%$. As the authors state, age is a key prognostic indicator for outcome [4]. The authors analysed patients who received VV-ECMO with or without ARDS,

This comment refers to the article available online at https://doi.org/10.1186/ s13054-021-03463-2.

*Correspondence: a.vuylsteke@nhs.net

${ }^{6}$ Royal Papworth Hospital, Papworth Road, Cambridge CB2 OAY, UK

Full list of author information is available at the end of the article reporting essentially identical mortality, and conclude that some of these patients may not have had an indication for ECMO support. We would suggest that the underlying pathophysiology may be more important than simply meeting definition criteria of ARDS. In our study, patients with certain underlying pathologies, such as asthma, were more likely to survive [2].

Although a lower short-term mortality per se does not necessarily mean a 'better' system, the benefit of experienced multidisciplinary teams-which include nursing, perfusion and therapy staff-concentrated in higher volume ECMO centres, is in our view inarguable. This experience does not just improve care for the individual patient, but also informs on patient selection, which is key to driving better outcomes. Furthermore, a centralised network with a single governance structure provides further advantages on equity of access and sharing best practice. For the above reasons, we would entirely agree with the authors' conclusions that 'treatment in specialised centres clearly results in reduced mortality.'

Yours sincerely,

\section{Authors' response}

Benjamin Friedrichson ${ }^{7 *}$, Haitham Mutlak7,8, Kai Zacharowski ${ }^{7}$ and Florian Piekarski ${ }^{7}$

*Correspondence: Benjamin.Friedrichson@kgu.de

${ }^{7}$ Department of Anaesthesiology, Intensive Care Medicine and Pain Therapy, University Hospital Frankfurt, Goethe University,

Theodor-Stern-Kai 7, 60590 Frankfurt am Main, Germany

${ }^{8}$ Department of Anaesthesiology, Intensive Care Medicine and Pain Therapy, SANA Klinikum Offenbach, Starkenburgring 66, 63069 Offenbach am Main, Germany., Theodor-Stern-Kai 7, 60590 Frankfurt am Main, Germany

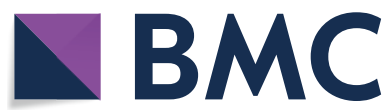

(c) The Author(s) 2021. Open Access This article is licensed under a Creative Commons Attribution 4.0 International License, which permits use, sharing, adaptation, distribution and reproduction in any medium or format, as long as you give appropriate credit to the original author(s) and the source, provide a link to the Creative Commons licence, and indicate if changes were made. The images or other third party material in this article are included in the article's Creative Commons licence, unless indicated otherwise in a credit line to the material. If material is not included in the article's Creative Commons licence and your intended use is not permitted by statutory regulation or exceeds the permitted use, you will need to obtain permission directly from the copyright holder. To view a copy of this licence, visit http://creativecommons.org/licenses/by/4.0/. The Creative Commons Public Domain Dedication waiver (http://creativeco mmons.org/publicdomain/zero/1.0/) applies to the data made available in this article, unless otherwise stated in a credit line to the data. 
To the editor

We would like to thank Drs. Warren et al. for their valuable letter, which underlines the impact of our recently published manuscript regarding ECMO therapy in Germany.

Data and especially the clinical setting published by Warren et al. are indeed completely contrary to the situation in Germany [5]. In addition to the lower number of centres in England compared to Germany, there is also a significantly lower ECMO incidence rate of approx. 3.05 per 1 million population compared to 18.28 per 1 million population [6]. Whether this clear difference is solely due to a different indication, e.g. inclusion of older patients, remains to be answered by further studies.

We agree with Warren et al. that a consideration of the underlying pathophysiology in acute respiratory syndrome (ARDS) makes an important difference in therapy and prognosis. Especially the mortality rates in H1N1 patients treated with ECMO have been shown to be lower than in other ARDS patients treated with ECMO [7]. The clinical entity of ARDS has multiple causes and is therefore particularly difficult to address in guidelines [8]. Currently, the final stage of the disease, i.e. refractory hypoxaemia, and its graduation, as well as the clinical course are the basic parameters used for ECMO indication. For this very reason, we are convinced that a centre formation with the experience, not only with regard to the interprofessional team, but also with regard to the underlying pathophysiology, can lead to a significant reduction in mortality. Analysing the underlying disease of ARDS is an important aspect; however, this was not possible due to the available data set of the Federal Statistical Office. We are convinced that a national registry for all ECLS treatments, as established in the United Kingdom, would be desirable for Germany. With the introduction of the German Interdisciplinary Association for Intensive and Emergency Medicine (DIVI) ECMO Covid-19 registry, a first step in the right direction has been taken [9].

Yours sincerely,

\section{Acknowledgements}

The authors acknowledge the other members of the NHS respiratory ECMO service steering group, Dr Julian Barker (Manchester, UK) and Mr Chris Harvey (Leicester, UK), and the staff of all participating hospitals.

\section{Authors' contributions}

All authors contributed substantially and revised the content and message of the manuscript.

\section{Funding}

None to declare
Availability of data and materials

None required.

\section{Declarations}

Ethics approval and consent to participate

None required.

\section{Consent for publication}

All authors consent to the publication of the manuscript.

\section{Competing interests}

None to declare.

\section{Author details}

${ }^{1}$ Division of Anaesthesia, University of Cambridge, Cambridge, UK. ${ }^{2}$ Department of Asthma, Allergy and Lung Biology, King's College London, London, UK. ${ }^{3}$ Guy's \& St Thomas' Hospital, London, UK. ${ }^{4}$ Royal Brompton \& Harefield Hospitals, London, UK. ${ }^{5}$ Aberdeen Royal Infirmary, Aberdeen, UK. ${ }^{6}$ Royal Papworth Hospital, Papworth Road, Cambridge CB2 OAY, UK.

Received: 19 February 2021 Accepted: 4 March 2021

Published online: 26 March 2021

\section{References}

1. Friedrichson $B$, et al. Insight into ECMO, mortality, and ARDS: a nationwide analysis of 45,647 ECMO runs. Crit Care. 2021;25:38. https://doi.org/10. 1186/s13054-021-03463-2.

2. Warren A, et al. Outcomes of the NHS England National Extracorporeal Membrane Oxygenation Service for adults with respiratory failure: a multicentre observational cohort study. Br J Anaesth. 2020;125(3):259-66. https://doi.org/10.1016/j.bja.2020.05.065.

3. Eurostat Population Database, https://ec.europa.eu/eurostat/web/produ cts-datasets/-/tps00001. Accessed 1Feb 2021.

4. Schmidt M, Bailey M, Sheldrake J, et al. Predicting survival after extracorporeal membrane oxygenation for severe acute respiratory failure The Respiratory Extracorporeal Membrane Oxygenation Survival Prediction (RESP) score. Am J Respir Crit Care Med 2014; 189: 137482

5. Warren A, Chiu YD, Villar SS, Fowles JA, et al. Outcomes of the NHS England National Extracorporeal Membrane Oxygenation Service for adults with respiratory failure: a multicentre observational cohort study. Br J Anaesth. 2020;125(3):259-66

6. Eurostat Population Database. https://ec.europa.eu/eurostat/web/produ cts-datasets/-/tps00001. Accessed 24 Feb 2021.

7. Davies A, Jones D, Bailey M, Beca J, et al. Extracorporeal Membrane Oxygenation for 2009 Influenza A(H1N1) Acute Respiratory Distress Syndrome. JAMA. 2009;302(17):1888-95.

8. Matthay MA, Arabi YM, Siegel ER, Ware LB, et al. Phenotypes and personalized medicine in the acute respiratory distress syndrome. Intensive Care Med. 2020;46(12):2136-52.

9. DIVI ECMO COVID-19 Registry. https://www.divi.de/forschung/laufendestudien/divi-ecmo-covid-19-register. Accessed 24 Feb 2021.

\section{Publisher's Note}

Springer Nature remains neutral with regard to jurisdictional claims in published maps and institutional affiliations. 